\title{
A Critique on the South Indian Labour Fund and the Malaysian Indian Plantation Workers
}

\author{
PUSHPAVALLI A RENGASAMEY \\ *SIVACHANDRALINGAM SUNDARA RAJA \\ ${ }^{1}$ Institut Pendidikan Guru Kampus Ilmu Khas, Bandar Tun Abdul Razak, Jalan Yaacob Latif, \\ 56000 Kuala Lumpur, Malaysia \\ ${ }^{2}$ Department of History, Faculty of Arts and Social Sciences, University of Malaya, \\ 50603 Kuala Lumpur, Malaysia \\ *Correponding author: siva@um.edu.my
}

Published online: 15 April 2020

To cite this article: Pushpavalli A Rengasamey and Sivachandralingam Sundara Raja. 2020. A critique on the South Indian labour fund and the Malaysian Indian plantation workers. KEMANUSIAAN the Asian Journal of Humanities 27(1): 115-133. https://doi.org/10.21315/ kajh2020.27.1.6

To link to this article: https://doi.org/10.21315/kajh2020.27.1.6

\begin{abstract}
This article offers a new perspective on Indian labour in colonial and independent Malaysia through analysis of an important financial resource, the Tamil Immigration Fund (established in 1907) which was subsequently renamed as Indian Immigration Fund (1912) and South Indian Labour Fund (1958). Contrary to the stated objectives of the fund, the colonial government and the post-independence Malaysian government failed to utilise the fund for the benefit of the Indian plantation workers. Existing literature on the fund and Indian labour in Malaya have not emphasised the fact that the fund was never used for the benefit of the South Indian labourers. The fund passed through four important phases in its development across a time span of close to 100 years from 1907-1999. The fund evolved from its role in supplying transient Indian labour force in the colonial period to becoming an agency promoting the welfare of Indian workers and their dependents who adopted Malaya as their own country in the early post-independence era. Unfortunately, the fund was dissolved under the premiership of Dr. Mahathir Mohamad and taken over by the Malaysian Government on 18th November 1999.
\end{abstract}

Keywords and phrases: South Indian labourers, plantations, welfare, South Indian Labour Fund, Malaya 


\section{Introduction}

The rapid increase in the production of commercial crops in British Malaya (a term which often used to refer to the Malay States under indirect British rule and it comprised the Straits Settlements, the Federated Malay States and the Unfederated Malay States) owed to the labour recruitment from India, China and Java. Prior to 1907, all recruitment of South Indian labourers to Malaya was carried out by professional recruiters. With labour shortage all over the country, managers who were not enterprising enough to recruit labourers from India started "crimping" labourers from other plantations. Labourers, whether indentured or free who were imported at considerable expense for a particular plantation, were attracted away by the promise of higher wages. This crimping of labour became common and many plantations that had expended large sums on importing labour found that, due to the constantly increasing demand, their newly acquired labour was attracted away elsewhere with heavy losses to themselves. Efforts to control crimping of labourers were unsuccessful and alarming owing to the very large demand for labour, fuelled by the rapid development of both the rubber and tin industries. Furthermore, labourers were also needed in the government services. Prominent planters' associations, such as the United Planters' Association, Johore Planters' Association and the Malay Peninsula Agricultural Association, compelled the government to establish a centralised system of registration of labourers to prevent crimping (Parmer 1960, 38).

The solution to the problems was found in 1907 in the form of the Tamil Immigration Fund Ordinance of 1907 (Tamil Immigration Fund Ordinance 1907a). It sought to encourage Indian immigration into Malaya by establishing the fund with contributions from the employers and the British government. The amount due by way of assessment was calculated from quarterly returns submitted by employers of Indian labour and the money collected was paid into the fund, which was to be utilised solely for financing the importation of South Indian labour (Swee-Hock 1980, 39). In the initial stage, the fund was launched with the help of loans mainly from the Federated Malay States (FMS) government ${ }^{1}$ and, to a lesser extent, from the Johore government. ${ }^{2}$ This method helped to meet immigration expenses incurred during the first quarter of 1908.

The Immigration Committee was authorised to manage the fund under Section 3 of the Tamil Immigration Fund Ordinance: Straits Settlements Ordinance, No. XVII (1907a). The committee also advised the government on questions related to the introduction of labour from India, Java and elsewhere and its employment in sectors such as plantation and public works. ${ }^{3}$ The inaugural meeting of the Immigration 
Committee was held in Pulau Pinang on 23rd March 1907. At its following meeting held on 14th April 1907, recommendations were made regarding rules for the operation of the Fund. After adoption by government, these recommendations were embodied in the Tamil Immigration Fund Ordinance (1907b) which was brought into force in the beginning of $1908 .{ }^{4}$ It was subsequently re-enacted with amendments as the Tamil Immigration Fund Ordinance (1907b). Under the Ordinance, all employers had to bear an equal share of the cost of importing Indian labour. It prevented the deduction of large amounts from the labourers' wages on account of recruiting expenses and thus deterred employers from paying high recruiting commissions to kanganies. Most importantly, it once and for all stamped out crimping. The Fund also attracted more workers by assuring good wages with moderate deductions and prevented malpractices by recruiters and kanganies. ${ }^{5}$

The Tamil Immigration Fund Ordinance was repealed by Labour Code (Enactment No. 6 of 1912) and the provisions of the Ordinance were incorporated in it. In May 1912, in accordance with Section 161(i) of the Labour Code (1912), the name of the fund was duly changed to the "Indian Immigration Fund" and managed by a quasi-official body called the Indian Immigration Committee.

The South Indian Labour Fund on the other hand came into existence on 1st September 1958 as a result of the passing of the South Indian Labour Fund Ordinance No. 24 of 1958. All the assets of the old Indian Immigration Fund which was set up in 1907 were wound-up on 31st August 1958 and transferred to the South Indian Labour Fund Board in accordance with the provisions contained in the Indian Immigration Funds (Winding-up) Ordinance No. 25 of 1958.

\section{Phase 1: South Indian Labour Fund during Colonial Era (1907-1938)}

During the first phase (1907-1938), the Tamil Immigration Fund focused on recruiting Indian labour on an organised basis from South India to Malaya; repatriating them from Malaya to South India and providing welfare services to Indian labourers. Initially, the fund paid for the free passages of independent labourers. Labourers in general were attracted by the fund Ordinance's assurances of reasonable wages with very little deductions. Later in the year, the fund was expanded to defray costs incurred in India, as well as the actual fare for the sea passage. Recruiting allowances were also covered from the fund for each adult labourer imported from India on condition that no deductions would be made from his wages on account of advances or expenses incurred in India. It was also used to build and run large emigration depots capable of housing thousands of labourers, such as at Avadi in Madras, Negapatnam and Papacovil. 
Most of the depots were equipped with water and electric supply as well as portions for sanitary, bathing and cooking. A general hospital and a special isolation ward were also maintained. The fund possessed two other depots. Before admission into these depots, all Indian labourers were examined medically and attempts made to ascertain if their proposed emigration had the consent of their relatives and friends. Just before departure from the depots, they were disinfected and provided with new clothing and sleeping mats (Majouribanks and Marakkayar 1917, 31). Operations and establishments in India were in the charge of the Emigration Commissioner for Malaya stationed at Avadi and the Assistant Emigration Commissioner at Negapatam.

From the beginning of 1912, the quarantine expenses of immigrants were paid for from the fund. ${ }^{7}$ In addition, the fund established an Old Folks Home in Circular Road, Kuala Lumpur in 1913 for the aged and infirm South Indians who did not want to return to India. The inmates were accommodated, fed and cared for at the expense of the fund. In 1914, the use of the fund was extended to pay the cost of local fares by bus, rail or steamer from the port of disembarkation in Malaya to the places of employment (Jackson 1961, 117-119).

With the introduction of the recruiting system set up under the fund, the problem of ensuring sufficient Indian labour supply for the newly-developing rubber estates had been solved (Jackson 1961, 121). The success of the fund in encouraging an increasing and steady flow of South Indian labour into Malaya was clear from the increased in demand of the professional service of kanganies and the immigration of assisted south Indians into Malaya.

The world economic recession (1929-1932) affected primary commodities like tin and rubber, which suffered the worst when labourers' wages were reduced from 50 cents to 20 cents and many were retrenched (Bauer 1961, 192). Since most of them were unskilled labourers, they found it difficult to be hired and became jobless. As a solution, the Immigration Restriction Ordinance was enacted in August 1930 to enable estate workers to leave Malaya (Netto 1961, 11). The Indian government was worried that any further reduction of wages would only create labour unrest in Malaya (Gangulee 1947, 128). Those who decided to stay put were paid meager wages compared to what they earned in 1929. The Malayan government had to comply with Indian rules on the need to take care of the welfare of the workers. The European planters were not keen to create a permanent labour force in Malaya (Gangulee 1947, 128) and to provide amenities. Efforts were even made to recruit Javanese labourers for the Netherland Indies (Gangulee 1947, 128). 
The British granted lands for the unemployed Chinese to undertake vegetable and food crop cultivation (Khoo 1977, 83; Brown 1986, 1007). In the 1930s, the number of Chinese squatters increased but British did not interfere as they supplied fresh vegetables and eggs (Khoo 1977, 83) and constituted a useful reservoir of casual labour. Thousands of Chinese were given Temporary Occupation Licences so that they could eventually be reused as labourers (Khoo 1977, 84). The licences given were revoked in 1934, when the depression was over, to ensure enough labour was available for the plantation and mining sectors. The Indians in the estate were neglected and land resettlement schemes, possibly through funds drawn from the fund, would have benefitted them. The fund could have also been utilised to transfer skills to the Indian workers who could then have become independent like the Chinese. There were only a few attempts to settle Indians like in the case of Chuah Settlement in Port Dickson and Sungai Ujong Settlement (Khoo 1977, 85).

In brief, during the first phase, the fund was mainly used for the recruitment of millions of south Indian workers and to fund their repatriation. During this period the fund was used to alleviate British economic problems in Malaya. However, the immigration function of the fund ended on 15th June 1938 when the Government of India banned assisted emigration of unskilled Indian labourers to Malaya. The ban stopped regular flow of labour from South India and virtually closed the chapter on the Indian Immigration Committee.

\section{Phase 2: South Indian Labour Fund during Crisis Era (1938-1958)}

The abolition of the Kangani system in 1938 which saw the end of recruitment of unskilled labourers has to be analysed within the broader context of political development in Malaya. Indian-based organisations in Malaya like the Central Indian Association of Malaya (CIAM) were very critical of the British rule and labour exploitation (Anbalakan 2008, 38-39). It highlighted the plight of Indian labour, contending that the immigration machinery was not designed to safeguard the interests of the labourers and that Indian immigrants had to be given full citizenship status (Ramasamy 1994, 28). The Indian government was then prompted to appoint Srinivasa Sastri to investigate the conditions of Indian labour in Malaya. In his report, Sastri stressed that Indian Immigration Committee was biased towards employers (Ramasamy 1994, 28).

With the Indian government's ban on assisted emigration of unskilled Indian labourers to Malaya on 15th June 1938, there had been no immigration of fresh Indian unskilled labour into Malaya. With the onset of Second World War and increased rubber production, planters believed that a labour shortage loomed. 
At the Indian Immigration Committee meeting held on 28th November 1941, rules and procedures for recruiting labour from Netherland East Indies were put forward. Following this development, the FMS, Straits Settlements (SS) and Johore Legislatures enacted the Indian Immigration Committee (Extension of Powers) Enactment 1941 (FMS Enactment No. 17 of 1941) ${ }^{8}$ which permitted the Indian Immigration Committee to levy and collect assessments and expend the balance of the fund's money, whose assets in 1941 totaled more than $\$ 4$ million, ${ }^{9}$ on the importation of Netherlands Indies or Javanese labour. ${ }^{10}$ These enactments had not been brought into force on the eve of the Japanese invasion (Parmer 1960, 45). ${ }^{11}$

Since the recruitment of Indian labourers into Malaya stopped in 1938, the fund was concerned only with the repatriation of the labourers if and when necessary. The fund was not used in the period of the war, despite hardship suffered by the estate workers who were recruited to work on the Japanese Siam-Burma railway. According to Netto $(1961,72)$, between 1942 and 1943, it was estimated that 75,000 Indian labourers from estates and government departments were brought to work in the railway construction. From this total, 45,000 labourers were reported to have died in Siam and their families in Malaya were left without any care. According to Kratoska $(1997,184)$, there were many of the labourers who were recruited to work in the death railway died due to malnutrition and diseases like malaria and skin ulcer. Indians were impoverished and the Indian population was markedly reduced. There was a significant drop in mortality rate among Indians - Stenson $(1980,90)$ estimates a drop of 100,000 or $7 \%$ whereas Kratoska $(1997$, 184) reports a reduction from $744,202(1941)$ to $599,616(1947)$ - more than $19 \%$. When British returned to rule under the British Military Administration (BMA) ${ }^{12}$ from September 1945 to April 1946, no effort was made to use the fund to uplift the social life of the Indians who were living under miserable conditions.

Nevertheless, the British appointed a new Indian Immigration Committee to oversee the fund. The Committee made an effort to trace all the relevant records and money amounting to 5 to 6 million dollars at the end of 1941. The BMA which took over the administration of Malaya after the war had to shoulder two great responsibilities: first, to take care of the welfare of those who suffered during the war and second, to rehabilitate the economy. To address the matter, BMA formed the Emergency Relief Committee and the Welfare Council to take care of those who suffered in the war and formed War Damage Compensation Fund to rehabilitate the plantation and mining sectors of the economy (Fujio 1993, 119-140). There were also other international bodies like the Silver Jubilee Committee, Australian Red Cross Society and Indian Red Cross Society that helped those who suffered in the war. Unfortunately, there was no effort on the part of the fund to help the workers who went through immense hardships during the war. It was clear that the 
British did not emphasise social welfare concerns of the Indian community in the plantation. After the war, political awareness among Indians led to the formation of Malayan Indian Congress (MIC) in 1946 to fight for the welfare of the Indians. MIC was aware of the need to voice the interest of plantation workers.

During the post-war years, the fund monies were spent mainly for the purpose of repatriating South Indian labour and their dependents who came into Malaya before 1938 and on whom assessment had been paid. Old and decrepit Indians, including widows and orphans, who were repatriated from the Federation of Malaya at the expense of the fund between September 1945 and 31st December 1948 amounted to 5,615 adults and 2,402 minors and the expenditure involved was $\$ 364,715.37 . .^{13}$ In addition, the fund was also used in assisting labourers in need of relief and as donations to orphanages and institutions which looked after orphans of the South Indian labourers.

With regard to the repatriation of Indian labourers in April 1949, the Indian Immigration Committee considered it fair to adopt a uniform system of allocating the cost of repatriating unfit Indian labourers, irrespective of the nature of disability, the question of gratuity and of whether they were employed by government, municipality or estates. ${ }^{14}$ As there was no further recruitment of Indian labourers and as the numbers repatriated during the 1950s had dwindled, the fund's largest depots at Avadi and Melpakkam were sold to the Madras Government in 1955 for ₹1.5 million (INR 1.5 million). Almost all the fund's employees in India had been retrenched, leaving only a skeletal staff to look after the remaining depots at Negapatam and Papacovil. Since 10th August 1956, none of the depots in India had been used for the onward transmission of repatriates because the Protector of Emigrants in Madras assured responsibility for receiving and ensuring repatriates were sent back home and villages on disembarkation. For some years, efforts were made to dispose of the depots at Negapatam and Papacovil and also evict illegal tenants on the land that the fund had purchased in 1920 at Coconada. However, they were not successful by 31st August 1958 when the Indian Immigration Fund was finally wound up in accordance with the Indian Immigration Funds (Windingup) Ordinance No. 25 of 1958 and all its assets and liabilities were taken over by the South Indian Labour Fund Board.

\section{Phase 3: South Indian Labour Fund during Post-Independence Era}

The South Indian Labour Fund's role in the third phase of development of the South Indian Labour Fund - from 1958 until 1970s - needs to be analysed within the context of Malaysian politics and economic development. There was a change of leadership in MIC after 1954. The party came under the leadership of Sambanthan 
in 1955 and became a Tamil party and the English educated withdrew their support for MIC (Arasaratnam 1970, 125). Urban middle class Indian participation in Indian politics was curtailed and its base shifted from KL to the plantation and small towns. Plantation labour was now organised into a strong union called National Union of Plantation Workers (NUPW) formed in 1954 (Arasaratnam 1970, 141). Trade unions were dominated by Indians both in membership and leadership but they were not able to fight for the rights of the labourers. At this time, MIC and NUPW functioned side by side as the political and economic custodians of Indian welfare. The alliance did not last long as they were suspicious of each other. In such a situation, the MIC was not able to fight effectively for Indian labour from the 1950s to 1970s. Although the post-independence era witnessed various economic initiatives carried out by the Alliance government, nothing concrete was done for the plantation workers. The Chinese had been assisted under the resettlement scheme mooted by Gerald Templer under Briggs Plan which saw Chinese being granted Temporary Occupation Licence (TOL) to open-up land for settlement and cultivation of agricultural crops (Lee and Tan 2000,259) and Rural Industrial Development Authority (RIDA) was formed in 1950 to help the Malays by providing basic infrastructure in the rural areas (Ramlah 1996, 9). Although the MIC did raise the matter with the government, the latter did not respond positively. This was no surprise as the Indians constituted only a negligible percentage of the electorate and the MIC leaders were ineffective spokesmen.

On the economic front, estate labourers were adversely affected when foreign owners sold their estates and left the country. Fragmentation led to thousands of Indian labourers losing their jobs. Indians who remained on the estates were forced settle for lower wages. They consequently had little access to afford health care and other facilities (Muzaffar 1993, 222). The MIC took steps to safeguard the welfare of the plantation community by establishing the National Land Finance Cooperative Society (NLFCS) in 1960 (Nagarajan 2007, 37). By 1969, the NLFCS had bought 18 estates. Both the MIC and NLFCS urged the government to institute control on the sale of estates over 100 acres (Sundara Raja and Raymond 2018, 16). Furthermore, the introduction of work permit policy in 1969 accentuated the weak economic position of Indian labourers (Anbalakan 2003, 267). As the policy required non-Malaysian citizens to apply for work permits, many locally born Indians who had failed to apply for citizenship were left out. The new policy was, in reality, introduced to solve the problem of unemployment especially among the Malays (Sundara Raja and Raymond 2018, 14). As a result, almost 60,000 Indian labourers were forced to leave Malaysia, while more than 50,000 were domiciled on the estates. They constantly feared of being repatriated as their contracts were yet to be renewed (Sandhu and Mani 1993, 186). 
These were the socioeconomic crises that the South Indian Labour Fund, which had been formed on 1st September 1958, through the passing of the South Indian Labour Fund Ordinance No. 24 of 1958, had to solve. All assets of the old Indian Immigration Fund which was set up in 1907 in accordance with the Tamil Immigration Fund Ordinance (1907) were wound-up on 31st August 1958 and transferred to the South Indian Labour Fund Board in accordance with the provisions contained in the Indian Immigration Fund (Winding-up) Ordinance No. 25 of 1958 . These assets as at 31st August 1958 amounted to $\$ 6,159,497.12$ and consisted of investments, both foreign and local, immovable property in India and cash in bank (as shown in Table 1). It was agreed that the one fourth share of the fund's investment assets was to be transferred to Singapore and the rest to the Federation of Malaya. ${ }^{15}$

Table 1. Financial assets of the Indian Immigration Fund

\begin{tabular}{|c|c|c|c|c|}
\hline \multicolumn{3}{|l|}{ Local investments } & \multirow[t]{2}{*}{$\begin{array}{l}\text { Foreign } \\
\text { investments }\end{array}$} & \multirow[t]{2}{*}{$\begin{array}{l}\text { Immovable } \\
\text { properties }\end{array}$} \\
\hline Debenture stock & Loan & $\begin{array}{l}\text { Saving and } \\
\text { current accounts }\end{array}$ & & \\
\hline $\begin{array}{l}\text { Pulau Pinang } \\
\text { Municipal } 1926 \\
(\$ 500,000) 5 \%\end{array}$ & $\begin{array}{l}\text { FMS Govt. } 1931 \\
(\$ 386,000) 4.5 \%\end{array}$ & $\begin{array}{l}\text { Federation of } \\
\text { Malaya treasury } \\
1952(\$ 200,000) \\
4.75 \%\end{array}$ & $\begin{array}{l}\text { British war } \\
\text { loan } 1932 \\
(\$ 3,564,445.36) \\
3.5 \%\end{array}$ & $\begin{array}{l}\text { A large depot } \\
\text { at Avadi near } \\
\text { Madras }\end{array}$ \\
\hline $\begin{array}{l}\text { Pulau Pinang } \\
\text { Municipal 1929 } \\
(\$ 131,650) 4.5 \%\end{array}$ & $\begin{array}{l}\text { SS Govt. War Loan } \\
1940(\$ 400,000) \\
3 \%\end{array}$ & $\begin{array}{l}\text { Chartered } \\
\text { bank savings } \\
\text { deposit accounts } \\
(\$ 20,000) 2.5 \%\end{array}$ & $\begin{array}{l}\text { Nyasaland stock } \\
1954-1974 \\
(\$ 85,714.29) 3 \%\end{array}$ & $\begin{array}{l}\text { An emigration } \\
\text { camp at } \\
\text { Melpakkam }\end{array}$ \\
\hline $\begin{array}{l}\text { Singapore } \\
\text { Municipal } 1948 \\
(\$ 258,000) \\
3.25 \%\end{array}$ & $\begin{array}{l}\text { FMS Govt. } 1941 \\
(\$ 85,000) 3 \%\end{array}$ & $\begin{array}{l}\text { Current account } \\
\text { at bank as on } 31 \mathrm{st} \\
\text { December 1957 } \\
(\$ 125,463.19)\end{array}$ & $\begin{array}{l}\text { Savings bond } \\
1960-1970 \\
(\$ 4,248.57) 3 \%\end{array}$ & $\begin{array}{l}\text { A depot at } \\
\text { Negapatam }\end{array}$ \\
\hline \multirow[t]{3}{*}{$\begin{array}{l}\text { Singapore } \\
\text { Municipal } 1930 \\
(\$ 500,000) 4.5 \%\end{array}$} & $\begin{array}{l}\text { Malayan Union } \\
\text { Loan } 1946 \\
(\$ 600,000) 3 \%\end{array}$ & & & $\begin{array}{l}\text { A depot at } \\
\text { Papacovil }\end{array}$ \\
\hline & $\begin{array}{l}\text { Federation of } \\
\text { Malaya } 1951 \\
(\$ 200,000) 3.75 \%\end{array}$ & & & $\begin{array}{l}\text { Land at } \\
\text { Coconada }\end{array}$ \\
\hline & $\begin{array}{l}\text { Federation of } \\
\text { Malaya Security } \\
\text { Loan } 1952 \\
(\$ 200,000) 4.75 \%\end{array}$ & & & \\
\hline
\end{tabular}


From being an agency that both recruited large numbers of workers for the booming rubber industry and repatriated them to their homeland when their contracts expired, the fund evolved in this phase to become one of the dynamic forces in the country helping to integrate the Indian workers and their dependents into Malaysian society. ${ }^{16}$ Since independence of Malaya in 1957, thousands of these Indian citizens became Malaysian citizens and adopted this country as their own. They did not wish to return to India. The fund recognised this fundamental change in the make-up and outlook of those of South Indian origin. Thus, the responsibility of the fund became even heavier. Therefore, Section 10 of the Ordinance lay down the purposes for which the fund may be disbursed. They include:

1. Repatriation of and grant of assistance to South Indian labourers and their dependents or orphans, who would have been eligible for such repatriation or assistance from the old Indian Immigration Fund.

2. Maintenance of aged or decrepit South Indian labourers and their dependents and orphans.

3. Acquisition, construction, maintenance and disposal of depots for housing South Indian labourers, either in the Federation or elsewhere.

4. Provision of welfare benefit for South Indian labourers in need of assistance.

The fund continued to be used for meeting the cost of repatriation of the workers and their dependants. Some 19,805 adults and 7,594 minors were repatriated to India from 1948-1999 at the expense of the fund. The Board formulated policies in considering applications for repatriation, and stipulated conditions for granting financial assistance from the fund for Indian labourers in need of relief. In addition, the fund also continued to maintain the Old Folks Home established in 1913 by the Indian Immigration Committee at Circular Road, Kuala Lumpur. The inmates were provided with food, clothing and medical attention, cash grants of $\$ 5$ per person per month and annual grants to celebrate Deepavali and Christmas in the Home. The fund even sponsored the building of an Old Folks Home in Nibong Tebal, Pulau Pinang on 15 acres of land which was donated by a philanthropist, Arumugam Pillai, at a cost of approximately $\$ 360,000$. The Home was officially opened by the Honorable Minister of Labour, V. Manickavasagam on 29th September 1966. This Home fulfilled a long-felt need; catered for the comfort and convenience of its residents and conveyed the sentiment that even the aged and the infirm Indian labourers had a stake in Malaysia. The fund also gave monthly pensions to many aged and infirm South Indian labourers who but preferred to live in the estates where they had been working for years. Thus, within the limited 
financial resources, the fund was doing its best to look after the aged and infirm South Indian labourers.

One of the most far-reaching and fruitful activities of the fund had been the granting of scholarship awards and study loans to deserving children of South Indian labourers since 1962. These scholarships were granted to children from secondary schools and those pursuing Higher School Certificate; as well as college and university students, mainly at University of Malaya, the College of Agriculture and the Technical College in Kuala Lumpur. No conditions were attached to the scholarships except that the student should study hard and make satisfactory progress in his course of studies. Therefore, the fund represented a unique and appropriate agency to meet the aspirations of the children of South Indian labourers to acquire a sound education. It has to be noted that after independence plantation children of South Indian origin were also given assistance by the South Indian Labour Fund, NUPW, NLFCS and various sources like the Tamil Youth Clubs, temples and individual philanthropists; however, no attempts were made by the MIC or the fund to persuade the plantation management to assist the children. Large firms like Guthries and Harrison and Crossfield should have been persuaded to offer scholarships or grants for children in their plantations. The fund should have also sought the support of organisations associated with plantation industry like Malayan Agricultural Producers Association (MAPA).

In addition, the fund provided annual financial grants to institutions to look after the orphans of South Indian labourers. They included the Convents' orphanages throughout Malaya: the Ramakrishna Orphanage, Pulau Pinang; the Pure Life Society, Puchong, Selangor; the Montfort Boys' Home, Batu Tiga, Selangor; St. Nicholas, Pulau Pinang; Little Sisters of the Poor, Pulau Pinang and Indian Childrens' Welfare Home, Taiping, Perak.

\section{Phase 4: South Indian Labour Fund in its Twilight Years (1980-1990s)}

Following the implementation of the New Economic Policy (NEP) to effect a social re-engineering and an affirmative action program to correct ethnic imbalances from the 1970s, the South Indian Labour Fund was pushed into obscurity. This is precisely because the main preoccupation of the policy to reassert indigenous Bumiputera control over politics and the economy led the South Indian Labour Fund into becoming an insignificant component of the national socioeconomic restructuring program. In the fourth phase (1980s-1990s), therefore, the South Indian Labour Fund often failed to receive the attention it deserved from Malaysian leaderships and, consequently, to take stock of the changes which were taking place 
in Malaysia. In 1980s, the function of the fund was limited to maintaining the Old Folks Home in Nibong Tebal and giving financial assistance to Indian labourers in need of relief. The fund faced continuous deficit for 14 years since 1983 resulting in its dependence for activities on its sole income from fixed deposits. Faced with this critical situation, the fund stopped giving out new study loans in 1987 (Abdul Wahab 1987, 3). Furthermore, there was no more application from Indian labourers for repatriation to India since 1990 (Tengku Dato Omar 1992, 12). The Board stopped taking in new inmates to the Old Folks Home in 1996 and by 1998 , there were only 22 inmates left in the home.

Furthermore, a study conducted by the Malaysian government in 1993 showed that the fund was no longer carrying out its main functions as stipulated in the South Indian Labour Fund Ordinance No. 24 of $1958 .{ }^{17}$ The then Human Resource Minister, Dato Lim Ah Lek criticised that the objectives of the fund appeared to be outdated (The New Straits Times, 1992). Due to these circumstances, the Malaysian cabinet decided to dissolve the South Indian Labour Fund Board on 26th May 1996 and all its functions were transferred to the Social Welfare Department within the next three years (Tengku Dato Omar 1997, 1-2).

The fund's beneficiaries who were the Indian Malaysian descendants of South Indian labourers were angered and unhappy with the government's decision to abolish the fund and transfer its assets worth RM2.36 million to state coffers. Non-governmental organisations (NGOs) and 17 Indian organisations such as Malaysian Tamil Youth Bell Club, Malaysian Hindu Sangam, Malaysian Hindu Youth Council and Malaysian Dravida Association were alarmed and rallied against the move by sending a joint memorandum to then Prime Minister, Datuk Seri Dr. Mahathir Mohamad urging him to withdraw the South Indian Labour Fund Bill (Dissolution Act 596, 1999) (The Star, 1999a). These groups were appalled by the fact that they were not consulted. They also protested the abolition of the fund, which they regarded with great historical value to the Indian community. Kulasegaran, an opposition member of Malaysian parliament, criticised that "the dissolution of the fund means putting away Indian hereditary rights into a coffin and then nailing away for good" (The Star, 1999b).

Many argued the government should have provided an alternative before abolishing the fund. The assets could have been utilised to construct a landmark in memory of the thousands of young South Indian workers who died of diseases, malnourishment and accidents in the early years of Malaya's economic development. The NUPW proposed that a South Indian Plantation Workers Education and Development Trust Fund be set up under the Trust Act 1959 to replace the South Indian Labour Fund. The NUPW also recommended that the land in Nibong Tebal be 
developed into an income-generating asset to provide a permanent income stream to the Trust Fund (The New Straits Times, 1999a). The Malaysian Trade Union Congress President, Zainal Rampak suggested that the South Indian Labour Fund be revamped to reflect national aspirations, renamed National Labour Fund and given more dynamic objectives (The New Straits Times, 1991).

The Group of Concerned Citizen's network of independent NGOs emphasised the importance of controlling and managing the assets in the interest of Indian Malaysians who had suffered socioeconomic neglect and marginalisation for almost a century (The New Straits Times, 1999b). It pointed out that the Indian community would inevitably be deprived if the assets were to be transferred to the government. Naturally, there were fears that some racially prejudiced civil servants would insist on doing things their way and ignoring government assurances (Wilford 2015, 87-101). Unfortunately, the MIC President, Samy Vellu and then Prime Minister, Tun Dr. Mahathir Mohamad downplayed these concerns as being politically motivated, contending that the opposition had engineered the protest to discredit the MIC. According to Mahathir:

The fund was formed by the British to take care of the Indian workers who were brought to Malaya. We are not South India, we are Malaysian and this fund was formed by the British mainly to recruit Indian workers from India to work here. Thousands perished due to malaria ... at that time the fund was important. But now Indians are well taken care of by the government and do we need to retain something which was started by the colonial masters? (Utusan Malaysia, 1999)

The spirit behind the reasoning was similar to that which gave rise to the London Dawn Raid in the 1980s whereby the locals wrested control of the plantation giant, Guthrie Corporation at the London Stock Exchange. The MIC, on the other hand, was at this time slowly losing its influence on national policies as evidenced in a number of issues which unfolded with the advent of intensified state-sanctioned positive discrimination measures for the bumiputeras from the 1970s associated with the NEP. Its lack of political ability to resist policies that were socioeconomically detrimental to the well-being of the south Indians was particularly evident in the late 1980s and 1990s. One such matter was the fragmentation of estates which continued unabated through the 1990s, after large corporations like Sime Darby, Guthrie and Boustead became Malaysian-owned. New townships and houses were built in former plantation areas to meet the high demand for private housing. Consequently, many estate workers became unemployed and were evicted from their homes (Tate 2008, 148). Several studies (Nagarajan 2007; Manickam 2009) reveal how plantation workers were evicted from their homes in the estates. 
The South Indian Labour Fund Bill (Dissolution Act 596, 1999) was passed in Parliament on 13th July 1999. This Bill authorised the government to take over the power, rights, privileges, responsibilities, financial matters, land, assets, liabilities and obligations vested with the South Indian Labour Fund Board (The New Straits Times, 1999c). Samy Vellu strongly supported the dissolution of the South Indian Labour Fund in Parliament because the decision was made collectively for the benefit of the Indians and for their betterment (The Sun, 1999a). Further he asserted that "I am not bothered by the noise made by these people who have no vision for the Indian community. None of their activities are going to divert our attention" (The Star, 1999c). However, as an afterthought, due to the persistent protests from NGOs, the Human Resource Ministry gave an assurance that the fund's assets would be used to build a skills training centre on the South Indian Labour Fund land in Nibong Tebal for the benefit of South Indian workers' children (The Sun, 1999b). Finally, the South Indian Labour Fund was dissolved on 1st November 1999 in accordance with South Indian Labour Fund Bill (Dissolution Act 596, 1999). The question is raised whether there might have been some political bargain that personally benefitted the politicians.

\section{Conclusion}

There is no doubt that the fund had played a vital role during British rule in Malaya. Without the fund, the British would not have been able to expand the rubber plantation sector from the late 19th century to the second half of the 20th century. It was clear that the fund was formed mainly to cater for the imperial interest and the welfare of workers was secondary. This was more apparent after the Second World War when there was no effort on the part of the British to use the fund to help the down trodden Indians who suffered great hardships, especially during the Japanese Occupation when they were forced into building the so-called Death Railway.

The fund steered off course after independence with little foresight on the part of the leaders to use it in the service of the Indians, especially when affirmative plans were in force for the Malays and Chinese in the late 1940s and early 1950s. The MIC which was the only party concerned with the welfare of the Indians did not have the requisite foresight to propose such amendments to the bylaws of the fund as would have enabled it to be utilised for the social mobility of the Indian workers. The scenario from the 1980s to the 1990s clearly showed that the fund had no clear direction due to poor leadership and the MIC's loss of grip on national politics. Its influence gradually diminished following the consolidation of Malay political power through the NEP and this situation became more obvious since 1974 when more parties joined the ruling coalition to form the Barisan Nasional 
(National Front). The new parties became more dominant in mainstream politics and MIC lost the leverage. Neither the grouses of the MIC nor the dissenting voices of the NGOs and opposition political parties were given serious thought. The MIC views had come to be sidelined and this was admitted by MIC leaders from 1970s until 2000. In the speech of the 23rd Annual General Assembly in 1975, Manickavasagam, the MIC President said:

In most cases, the problems that we in the MIC are raising are problems of implementation. We have a saying in Tamil that "even if God is prepared to concede the priest remains an obstacle". While at the top levels of government, we share a clear perception of the goals and direction of national effort, down the line of bureaucracy - in departments, districts or agencies of government and universities - the vision gets blurred or distorted, leading us to the problem we are now facing.

Similar grouses were voiced by the then MIC President, Dato' Seri S. Samy Vellu at the 62 nd MIC General Assembly on 13th July 2008. According to him:

The real cause of this (lack of support from Indians for the Barisan Nasional coalition) is poverty and difficulty in obtaining loans and places in universities. ...we raised this a long time ago with the government but the government was slow to take action. My question is why was it so delayed? (The Sun, 2008)

It could be summed-up that despite legitimate criticisms, the British could at least be credited with a broader perspective and fairer sense of justice; unfortunately, it was not the same under the local leaders after independence when no effort was made to adapt the role of the fund to meet the needs of the plantation workers according to changing times. The Indians were neglected a lot in colonial days, and more so in present day Malaysia.

\section{Notes}

1. Resident General Office, 5881/1907, Issues of free passages under the Tamil Immigration Fund Enactment to begin from 12th February 1908.

2. General Advisor Johore, 1052/1907, Proposed subsidy by the Johore government of $\$ 5,000$ a year towards the Indian Immigration Scheme.

3. Refer Federated Malay States $(1907,7)$, Report on Indian immigration and emigration for the year 1907. Also, refer The annual report of the Indian Immigration Department for the year 1906 (p. 21).

4. Refer Tamil Immigration Fund Ordinance (1907a, 25-26), Straits Settlements Government Gazette, 3.1.1908 and Tamil Immigration Fund Ordinance (1907b, 88), Straits Settlements Government Gazette, 10.1.1908. Also refer Straits Settlements Annual Report, 1908. 
5. Refer Federated Malay States $(1907,8)$, Report on Indian immigration and emigration for the year 1907.

6. The changes in name reflect the changing objectives of the fund.

7. Refer Federated Malay States (1912, 27-28), Report on the working of the Labour Department for the year 1912.

8. Refer General Advisor Johore, 441/1940, Encouragement of the immigration of Javanese labourers into Malaya.

9. The currency used was Straits Dollar until 1939 and after that was Malaya Dollar.

10. A Labour Department memorandum written in 1935 had also anticipated the Indian ban and had suggested that the Indian Immigration Fund to be used to promote Chinese or Javanese immigration.

11. In 1948, Recruitment of Indigenous Labour Bill came up for consideration but it was not adopted by the Indian Immigration Committee due to persistent protests from Indian intellectuals.

12. British Military Administration (BMA) was established by the British Military Chief Commander, Lord Louis Mountbatten, on 15th August 1945. It was responsible for the administration of the redevelopment of the influence of the British in Malaya after the Japanese occupation.

13. Refer Federation of Malaya (1949, 13), Report of proceedings of Legislative Council.

14. Refer Federal Secretariat Circular No. 29 of 1949. In Selangor Secretariat, 2187/1949, Apportionment of costs of repatriation of South Indian labourers.

15. Refer Legislative Council Debates (1959, 4346-4347), Official report of the second Legislative Council of the Federation of Malaya (third session), September 1957 to October 1958. Kuala Lumpur: Government Press.

16. Speech by the Hon'ble the Minister of Labour, Tuan V. Manickavasagam, in declaring open the Second Home of the South Indian Labour Fund Board at Nibong Tebal, Province Wellesley on 29th September 1966.

17. Refer Legislative Council Debates (1999, 48). Official Report of the Second Legislative Council of the Federation of Malaya, for the period (fifth session), 13 July 1999. Kuala Lumpur: Government Press.

\section{Bibliography}

Abdul Wahab. 1987. Annual report of South Indian Labour Fund. Kuala Lumpur: Labour Department.

Anbalakan, K. 2008. Identiti India di Malaysia. Pulau Pinang, Malaysia: Penerbit Universiti Sains Malaysia.

2003. The NEP and further marginalisation of the Indians. Kajian Malaysia 21(1\&2): 379-398.

Arasaratnam, S. 1970. Indians in Malaysia and Singapore. Kuala Lumpur: Oxford University Press.

Balakrishnan, G. 2000/2001. South Indian Labour Fund. BA academic exercise, University of Malaya, Kuala Lumpur. 
Bauer, P.T. 1961. The workings of the Rubber Regulation. In Readings in Malayan economics, ed. T.H. Silcock. Singapore: Eastern University Press, 242-267.

Brown, I. 1986. Rural distress in Southeast Asian during the World Depression of the early 1930s: A preliminary examination. Journal of Asian Studies 14(5): 995-1025. https://doi.org/10.2307/2056606

Federated Malay States. 1920. Report of a meeting of the General Labor Committee, British Malaya, held at 12, Market Street, Kuala Lumpur on 31st May 1920. Kuala Lumpur: The Malayan Leader Press.

1913. Annual report of the Indian Immigration Fund. Kuala Lumpur: Government Press.

1912. Report on the working of the Labour Department for the year 1912. Kuala Lumpur: Government Press.

1907. Report on Indian immigration and emigration for the year 1907. Kuala Lumpur: Government Press.

Federation of Malaya. 1949. Report of proceedings of Legislative Council.

Fujio, H., ed. 1993. Japan and Malaysian economy: An analysis of the relations started with reparations after the end of World War II. In Formation and restructuring of business groups in Malaysia, 119-140. Tokyo: Institute of Developing Economics.

Gangulee, N. 1947. Indians in the empire overseas: A survey. London: The New India Publishing House.

General Advisor Johore. 1052/1907, Proposed subsidy by the Johore government of \$5,000 a year towards the Indian Immigration Scheme.

441/1940, Encouragement of the immigration of Javanese labourers into Malaya.

Jackson, R.N. 1961. Immigrant labour and the development of Malaya. Kuala Lumpur: Government Press.

Khoo Kay Kim, ed. 1977. The Great Depression: The Malaysian context. In The history of South-East, South and East Asia: Essays and documents, 78-94. Kuala Lumpur: Oxford University Press.

Kratoska, P.H. 1997. Japanese occupation of Malaya: A social and economic history. London: C. Hurst.

Lee, K.H. and Tan, C.-B., eds. 2000. The Chinese in Malaysia. Selangor, Malaysia: Oxford University Press.

Legislative Council Debates. 1999. Official report of the second Legislative Council of the Federation of Malaya, for the period (fifth session), 13 July 1999. Kuala Lumpur: Government Press.

. 1959. Official report of the second Legislative Council of the Federation of Malaya, for the period (third session), September 1957 to October 1958. Kuala Lumpur: Government Press.

Mahajani, U. 1973. The role of Indian minorities in Burma and Malaya. Westport, CT: Greenword Press.

Majouribanks, N.E. and Marakkayar, A.K.G.A.T. 1917. Report on Indian labour emigrating to Ceylon and Malaya, 1917. Madras: Government Press.

Malay Mail. 1907. The objective of the Bill, 3 September. 
Manickam, J.R. 2009. The Malaysian Indian dilemma: The struggles and agony of the Indian community in Malaysia. Selangor, Malaysia: Nationwide Human Development and Research Centre.

Manikam, O.G. 1993/1994. Sejarah penubuhan dan perkembangan Tabung Imigresen India (1907) di Tanah Melayu sehingga tahun 1990, BA academic exercise, Universiti Kebangsaan Malaysia, Selangor.

Muzaffar, C. 1993. Political marginalization in Malaysia. In Indian communities in Southeast Asia, eds. K.S. Sandhu and A. Mani, 211-236. Singapore: Time Academic Press.

Nagarajan, S. 2007. The Indian community and the NEP in Malaysia. Paper presented at the CRISE/ARI Workshop on Affirmative Action: Malaysia in International Comparative Perspective, Singapore, 22-23 October.

2004. A community in transition: Tamil displacements in Malaysia. PhD diss., University of Malaya, Kuala Lumpur.

n.a. 1908. Straits Settlements annual report 1908. Kuala Lumpur: Government Press.

n.a. 1906. The annual report of the Indian Immigration Department for the year 1906. Kuala Lumpur: Government Press.

Netto, G. 1961. Indians in Malaya. Singapore: George Netto.

Parmer, J.N. 1960. Colonial labour policy and administration. New York: Asian Studies Association.

Ramasamy, P. 1994. Plantation labour, unions, capital and the state in Peninsular Malaysia. Kuala Lumpur: Oxford University Press.

Ramlah Adam. 1996. Ekonomi Masyarakat Melayu pada 1951-1955: Aktiviti RIDA, UMNO, dan Dato’ Onn Jaafar. Kajian Malaysia, XIV (1\&2): 1-35.

Resident General Office. 5881/1907, Issues of free passages under the Tamil Immigration Fund Enactment to begin from 12th February 1908.

Sandhu, K.S. 1969. Indians in Malaya: Some aspects of their immigration and settlement (1786-1957). London: Cambridge University Press.

Sandhu, K.S. and Mani, A.K. 1993. Indian communities in Southeast Asia. Singapore: Times Academic Press.

Selangor Secretariat. 1949. Federal Secretariat Circular No. 29 of 1949. In Selangor Secretariat, 2187/1949, Apportionment of costs of repatriation of South Indian Labourers.

Stenson, M. 1980. Class, race and colonialism in West Malaysia: The Indian case. St. Lucia: University of Queensland Press.

Sundara Raja, S. 2003. Kajian awal sejarah dan perkembangan Tabung Pekerja India, 1907-1999. Purba: Jurnal Persatuan Muzium Malaysia 22: 41-52.

Sundara Raja, S. and Raymond, S. 2018. The lost race in British Malaya: Revisiting the problems of South Indian labourers. Diaspora Studies 11(2): 115-134.

Swee-Hock, S. 1980. Indian immigration in Malaya before the Second World War. Malaysia in History 23: 47-58.

Tamil Immigration Fund Ordinance. 1907a. Straits Settlements Government Gazette, 3 January 1908. Kuala Lumpur: Government Press.

1907b. Straits Settlements Government Gazette, 10 January 1908. Kuala Lumpur: Government Press. 
Tate, M.D. 2008. The Malaysian Indians: History, problems and future. Selangor, Malaysia: Strategic Information and Research Development Centre.

Tengku Dato Omar. 1997. Annual report of South Indian Labour Fund. Kuala Lumpur: Government Press.

1992. Annual report of the South Indian Labour Fund. Kuala Lumpur:

Government Press.

The New Straits Times. 1999a. Reconsider decision to dissolve fund: MTUC, 15 July. 1999b. Estate workers need skills development centre, 14 July 1999c. Dissolution of fund "meant to help Indians", 14 July 1992. Aims of labour fund may be reviewed, 10 August. 1991. MTUC: Revamp South Indian Labour Fund, 16 September.

The Star. 1999a. Don't dissolve fund, groups plead, 12 July. 1999b. Dissolution of fund end hereditary rights, 11 July. 1999c. Samy supports dissolution of Fund, 12 August.

The Sun. 2008. The cause for lack of support for Barisan Nasional, 31 March. 1999a. Fund's assests will be used to build skills training centre, 18 July. 1999b. South Indian Labour Fund land to be used for building vocational institute, 14 July.

Utusan Malaysia. 1999. South Indian Labour Fund (Dissolution Act 1999), 18 July. Wilford, A.C. 2015. Tamils and the haunting of justice: History and recognition in Malaysia's plantations. Singapore: National University of Singapore Press. 